\title{
Tsunami hazard assessment in the coastal area of Rabat and Salé, Morocco
}

\author{
C. Renou ${ }^{1}$, O. Lesne ${ }^{1}$, A. Mangin ${ }^{1}$, F. Rouffi ${ }^{1}$, A. Atillah ${ }^{2}$, D. El Hadani ${ }^{2}$, and H. Moudni ${ }^{2}$ \\ ${ }^{1}$ ACRI-ST, 260 Route du Pin Montard, BP234, 06904 Sophia-Antipolis Cedex, France \\ ${ }^{2}$ Centre Royal de Télédétection Spatial, Rabat, Morocco
}

Received: 17 September 2010 - Revised: 7 April 2011 - Accepted: 13 April 2011 - Published: 10 August 2011

\begin{abstract}
In the framework of the three-year SCHEMA European project (www.schemaproject.org), we present a generic methodology developed to produce tsunami building vulnerability and impact maps. We apply this methodology to the Moroccan coast. This study focuses on the Bouregreg Valley which is at the junction between Rabat (administrative capital), and Salé. Both present large populations and new infrastructure development. Using a combination of numerical modelling, field surveys, Earth Observation and GIS data, the risk has been evaluated for this vulnerable area.

Two tsunami scenarios were studied to estimate a realistic range of hazards on this coast: a worst-case scenario based on the historical Lisbon earthquake of 1755 and a moderate scenario based on the Horseshoe earthquake of 28 February 1969. For each scenario, numerical models allowed the production of tsunami hazard maps (maximum inundation extent and maximum inundation depths). Moreover, the modelling results of these two scenarios were compared with the historical data available.

A companion paper to this article (Atillah et al., 2011) presents the following steps of the methodology, namely the elaboration of building damage maps by crossing layers of building vulnerability and the so-inferred inundation depths.
\end{abstract}

\section{Introduction}

Among African countries, Morocco is probably one of the most exposed to tsunami hazard. Indeed, Morocco is integrated in the particular geodynamic context of the northern African margin, which is characterized by the existence of the western segment of the Eurasia-Nubia plate boundary separating two active tectonic plates: the African and

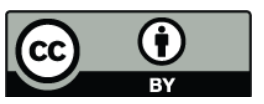

Correspondence to: $\mathrm{C}$. Renou (camille.renou@acri-st.fr) the Eurasian plates. This area has generated and still generates many large earthquakes exceeding a magnitude of 6 . The Moroccan Atlantic coasts, like the Portuguese and Spanish coastal regions, are thus exposed to various tsunamigenic earthquakes occurring offshore. Tsunamis generated in this area are not frequent but could be really disastrous and have a huge impact.

\subsection{Atlantic marine seismic sources}

The tectonic activity of the northwestern African plate and the Eurasian plate is governed by different tectonic structures with different regimes: an extensional regime near the Azores archipelago; a lateral strike-slip regime moving at $\sim 4.7 \mathrm{~mm}$ year $^{-1}$ (Serpelloni et al., 2007) along the fault Azores-Gibraltar (Gloria Fault); and a compressional regime moving at $\sim 1.5 \mathrm{~mm}$ year $^{-1}$ from the Gorringe Bank to the Gulf of Cadiz (Fig. 1). This significant tsunamigenic zone is characterized by many large earthquakes exceeding a magnitude of 6 .

Among the Atlantic tsunamis sources having affected Morocco, researchers reported historical cases of tsunami: $60 \mathrm{BC}, 382$ and 1773. But the perfect illustration of this seismic activity is the devastating tsunami generated by the famous Great Lisbon Earthquake that occurred in $1755\left(M_{\mathrm{w}} 8.3-8.5\right)$ and reported in historical documents. In addition to the Portuguese and Spanish coasts, it affected the western coasts of Morocco and destroyed parts of Tangier, Asilah, Larache, Mehdia, Salé, Rabat, Casablanca and Safi (Fig. 2). The General Fowke mentioned in 1756 great damages in Salé (Kaabouben et al., 2009). According to the historical description, the inundation is estimated to have impacted at the most $2 \mathrm{~km}$ inland. In Rabat city, two hundred people were drowned (El Mrabet, 1991).

But, if the 1 November 1755 event is the best described due to its impact, however, the location of the earthquake source remains uncertain. First multi-channel seismic

Published by Copernicus Publications on behalf of the European Geosciences Union. 


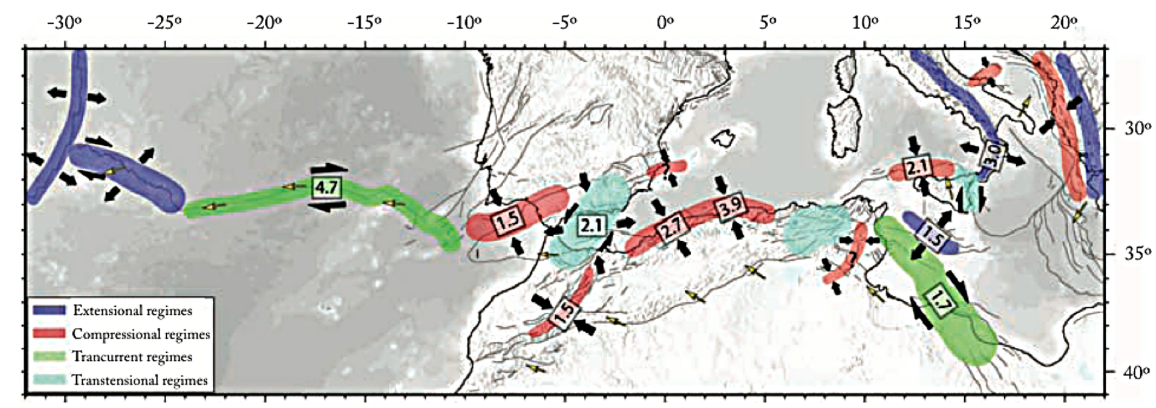

Fig. 1. Present-day tectonic sketch of the Nubia-Eurasia boundary. Deformation rates are in mm year ${ }^{-1}$ (from Serpelloni et al., 2007).

Table 1. Source parameters (Baptista et al., 2003), L: the fault length in kilometers; W: the fault width in kilometers.

\begin{tabular}{lllllllll}
\hline \multirow{2}{*}{$\begin{array}{l}\text { Scenario } \\
\text { Name }\end{array}$} & \multicolumn{6}{l}{ Marques de Pombal Thrust Fault } & \multicolumn{9}{c}{ Guadalquivir bank } \\
$\mathrm{L}(\mathrm{km})$ & $\mathrm{W}(\mathrm{km})$ & Strike $\left(^{\circ}\right)$ & $\mathrm{L}(\mathrm{km})$ & $\mathrm{W}(\mathrm{km})$ & Strike $\left({ }^{\circ}\right)$ & Slip $(\mathrm{m})$ & $\operatorname{Dip}\left({ }^{\circ}\right)$ \\
\hline 1755 & 105 & 55 & 21.7 & 96 & 55 & 258.5 & 20 & 24 \\
\hline
\end{tabular}

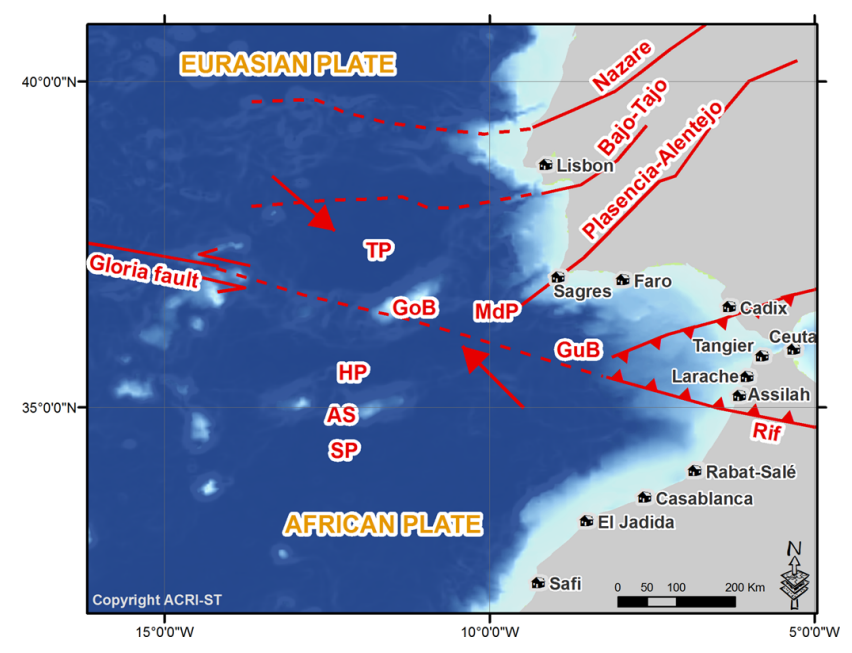

Fig. 2. Tectonic sketch map of the study region. Abbreviations: TP: Tagus Plain; GoB: Gorringe Bank; HP: Horseshoe Plain; AS: Ampere Seamout; SP Seine Plain; MdP Marques de Pombal; GuB: Guadalquivir Bank.

reflection surveys performed in 1992 allowed the indentification of a large active, compressive, tectonic structure, called the Marques de Pombal thrust, located $100 \mathrm{~km}$ offshore SW Sagres; this was considered as a possible origin of the 1755 earthquake (Zitellini et al., 1999; Fig. 2). But this source was unable to account for the total seismic energy released during this earthquake. A second campaign was then performed in the area located between the Gorringe bank, the SW Iberian coast and the Gulf of Cadiz (Zitellini et al., 2001) and this allowed the detection of new active tectonic structures, suggesting a possible composite source (Baptista et al., 2003; Gutscher, 2004; Zitellini et al., 2001; Table 1).
On the 28 February 1969, the coasts of Portugal, the Azores, Spain, Canary Islands and Morocco were affected by a smaller tsunami generated by a submarine earthquake $\left(M_{\mathrm{S}} 7.9\right.$; Table 2$)$ with an epicentre located south of Gorringe bank near the Azores-Gibraltar fracture zone (Fukao, 1973; Guesmia et al., 1998). This is the most important event in terms of impact which occurred in the last century. The fact that it happened during the night at 02:40 reduced the number of eyewitness reports. The maximum amplitude can be estimated at $0.9 \mathrm{~m}$ at Casablanca according to the tide gauge record of the harbour of Casablanca (Kaabouben et al., 2009). The Moroccan newspaper "Al Alam" from 1 and 2 March 1969 related the behaviour of people, distressed by the strong shock, and a strong agitation of the sea mainly in Rabat and Salé during the night. According to Baptista and Miranda (2009) and Omira et al. (2009), a dataset of at least 13 tide records were obtained and processed in order to locate the tsunami source.

\subsection{Moroccan site}

The Moroccan site chosen for this study is located on the Atlantic coast in the "Rabat Zaiir" region. Centred on the Bouregreg Valley, it covers two main coastal and densely populated towns of Morocco: Rabat (administrative capital) and Salé. The studied area is centred on the Bouregreg estuary. It extends over $10 \mathrm{~km}$ along the coast and $10 \mathrm{~km}$ inland along the Bouregreg river.

The choice of the region of Rabat-Sale is motivated by many factors such as the high concentration of population (1.8 million inhabitants), the high vulnerability of buildings and infrastructures, narrow beaches with many tourists in summer, the presence of several bridges on the Bouregreg river separating Rabat and Salé, the presence of a dam 
Table 2. Source parameters (from Fukao, 1973), L: the fault length in kilometers; W: the fault width in kilometers; D: the depth from the sea bottom to the top of the fault in kilometers; $\mu$ : the shear modulus and $M_{\mathrm{W}}$ : the moment magnitude.

\begin{tabular}{llllllllllll}
\hline $\begin{array}{l}\text { Scenario } \\
\text { name }\end{array}$ & $\begin{array}{l}\mathrm{L} \\
(\mathrm{km})\end{array}$ & $\begin{array}{l}\mathrm{W} \\
(\mathrm{km})\end{array}$ & \multicolumn{2}{l}{$\begin{array}{l}\text { Epicenter coordinates } \\
\text { Lon }\end{array}$} & $\begin{array}{l}\text { Lat } \\
(\mathrm{km})\end{array}$ & $\begin{array}{l}\text { slip } \\
(\mathrm{m})\end{array}$ & $\begin{array}{l}\text { Strike } \\
\left({ }^{\circ}\right)\end{array}$ & $\begin{array}{l}\text { Dip } \\
\left({ }^{\circ}\right)\end{array}$ & $\begin{array}{l}\text { Rake } \\
\left({ }^{\circ}\right)\end{array}$ & $\begin{array}{l}\mu \\
(\mathrm{Pa})\end{array}$ & $M_{\mathrm{W}}$ \\
\hline 1969 & 80 & 50 & -10.57 & 36.01 & 22.0 & 3.0 & 235.0 & 52.0 & 90.0 & $4.0 \times 10^{10}$ & 7.9 \\
\hline
\end{tabular}

upstream of the 2 cities, the new development project of the Bouregreg Valley (residential and touristic complex), but also because this region had already been affected by the 1755 tsunami triggered by the great Lisbon earthquake.

\section{Logical approach}

To assess the tsunami hazard of Rabat-Sale region, we applied the global methodology developed during the SCHEMA project ${ }^{1}$ (Tinti et al., 2011).

\section{Selection of the potential sources}

This methodology consists in modelling for a given type of source (earthquake/landslide/etc....) each potential scenario of tsunami in a given area for different levels of tide. The first step is to make an inventory of the sources that may have the highest tsunamigenic potential for the considered test site. The worst-case tsunami scenarios are defined by bibliography, seismotectonic studies of earthquake and tsunami catalogues. Although our sources are based on historical occurrences, the goal is not to achieve a reconstruction of the historical tsunami, but simply that the historical tsunamis are used as a good example upon which to base the scenarios.

\section{Scenario modelling}

Futher to the selection of the sources for a given test site, numerical simulations of the tsunami scenarios were then performed. Uncertainties on the results of computations depended on a very large number of factors such as: scientific considerations that induce a lack of objectiveness in the scenario sources, the quality of the tsunami simulation model, the quality of the topographic and bathymetric data set, etc.... In the SCHEMA methodology, the uncertainty problem has been addressed by assuming that in addition to the standard scenarios, a parallel series of "augmented source" scenarios should have been developed: the amplitude of the initial tsunami wave was increased by $20 \%$ for each earthquake source. The scenario elaborated with the amplified source is

\footnotetext{
${ }^{1}$ SCHEMA (Scenarios for Hazard-induced Emergencies Management) European Project no. 030963, Specific Targeted Research Project, Space Priority, from August 2007 to October 2010. It has been funded within the 6th Framework Programme.
}

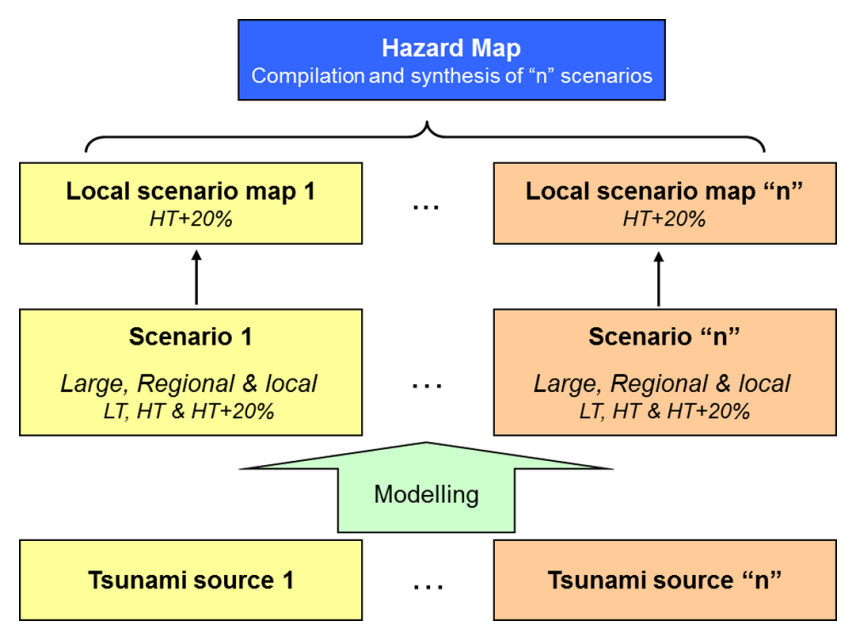

Fig. 3. Logical approach for tsunami hazard assessment.

named "augmented scenario" while the one with the reference size is simply called "scenario".

For each source and each tide level (low and high tides), reference and augmented scenarios were modelled and allowed maximum water elevations, inundation depths, extents of inundation and current velocities to be obtained.

\section{Hazard map}

After modelling each individual tsunami scenario and its impact on the coastal zone, tsunami hazard scenario was generated by combining the effects of all the sources (Fig. 3). This aggregate scenario corresponds to the worst-case credible scenario. Sometimes, although different tsunamigenic sources were chosen, only one appears to be relevant for the analysis of hazard map. This is a factor providing a strong argument against the adoption of a probabilistic approach for scenario construction.

\section{Building vulnerability map}

Tsunamis can affect buildings with various intensity depending on several factors: intrinsic building vulnerability factors (resistance properties of buildings) and environmental vulnerability factors (density of buildings per unit area, road width, presence of floating objects, etc...). Environmental 
factors are not building properties strictly speaking but may intensify the impact of a tsunami wave on the buildings structures.

The building typology used to classify intrinsic vulnerability is principally derived from data and previous works by Leone et al. (2010), Peiris (2006) and Garcin et al. (2007), but has been completed and enlarged in order to be more general and to include at least all constructions present in the five test sites of the SCHEMA project (Valencia et al., 2011; Atillah et al., 2011). The building classes are defined by different categories mainly depending on the construction material (wood, clay, bricks, reinforced concrete, etc. ...), structural characteristics (beams, columns, etc....) and the number of building storeys.

\section{Building damage map}

Finally, the damage map is then derived by crossing information from the hazard map, and more particularly the inundation depths, with the building vulnerability map using the DamASCHE tool on ArcInfo (ESRI) developed during the SCHEMA project. This tool uses a damage matrix that gives the expected level of damage for each building according to its building class and the estimated inundation depth at its location. In order to obtain the damage matrix, fragility curves have been derived using previous works performed by Leone et al. (2010) and Peiris et al. (2006) and have been completed for each building class defined above (Valencia et al., 2011; Tinti et al., 2011).

Maps of potential environmental factors (secondary or external factors) that may increase/decrease the intensity of destruction are produced independently from damage maps, in order to bring additional information helping to apprehend the degree of risk in case of their presence.

\section{Atlas}

An atlas summarizing all maps of a test site (tsunami hazard, building vulnerability and building damage levels) is created to disseminate these results to end users (Civil Protection, Moroccan Red Crescent, Direction of Ports, Local Authorities, etc....).

In this paper, we present the results for the hazard assessment in the coastal area of Rabat-Sale (Morocco). The vulnerability and damage assessment is described in Atillah et al. (2011).

\section{Numerical modelling}

We used the TIDAL software (see http://www.acri-in.fr/ software/tidal), a general-purpose software tool for fluid flow, heat and mass transfer problems in shallow water bodies. It can be used to simulate transient or steady state problems in a water body with irregular coastline, complex bathymetry and islands. TIDAL uses a Boussinesq approximation of the Navier-Stokes equations.

The numerical model uses a nested grid system with different grid resolutions. First an independent oceanic model is run to generate and propagate the wave, the shape and height of wave structures being pre-computed. The boundary conditions of the local model are then extracted from this largescale model.

Initial conditions can be computed from the analytical formulas of either Kajiura (1970), Mansinha et al. (1971), Okada (1992) or Abe (1993) for seismic sources or extracted from pre-computed external data (which is the case of the present study).

The computing grids are Cartesian and structured. There is a flexibility to refine grids in one or two dimensions but it is not a suitable solution when addressing large areas. Therefore, we preferred to nest three models at different spatial resolutions to focus on local specificities.

In this study, the tsunami propagation from the source to the coast was thus simulated using nested models at three different scales: large (oceanic propagation level), regional and local, with grid resolutions of $3.7 \mathrm{~km}, 50$ to $250 \mathrm{~m}$ (irregular grid) and $20 \mathrm{~m}$, respectively (Figs. 6 and 7).

\subsection{Scenario data}

The Digital Elevation Model was generated from a compilation of multisource of height and depth data. Bathymetry result from GEBCO $^{2}$ data at 1 arc minute grid and 30 arcsecond grid scales, digitalised cartographic data at 1:153 400 scale (SHOM map number 6145) and digital depths of the Bouregreg river bed at $1 \mathrm{~m}$ resolution (data obtained after the Bouregreg dredging in 2009). Otherwise, topographic data have been provided by CRTS with a resolution of $1 \mathrm{~m}$ subsampled to $20 \mathrm{~m}$ on Rabat and Salé cities. This topography takes into account building representation.

To be compatible, all topographic and bathymetric data have been integrated into a unique reference frame: the Lowest Astronomical Sea Level (LASL). This reference has been defined using the lowest levels recorded by tide gauges in the harbour of Rabat during the whole year 2008 and corresponds to our low tide case in our models. Also, all data were merged on a unique database and transformed to WGS84/UTM coordinates (fuse $29^{\circ} \mathrm{N}$ ).

\subsection{Tsunami source}

Only one source appears to be relevant for the worst case scenario on the coastal zone of Rabat-Salé. This is the 1755 Lisbon earthquake, also known as the Great Lisbon Earthquake, that occurred on the morning of 1 November 1755

\footnotetext{
2 GEBCO (General Bathymetric Chart of the Oceans) - The GEBCO One Minute Grid, a global one arc-minute grid; Released: 2003, updated: 2008.
} 

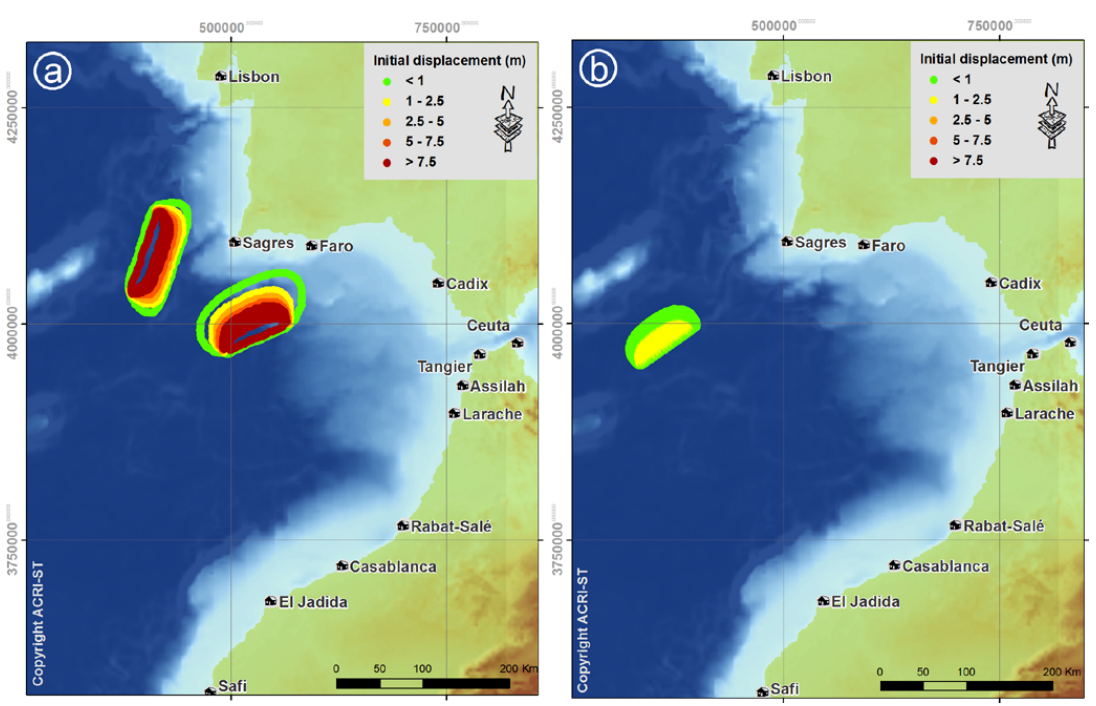

Fig. 4. Initial displacement (localisation and initial wave height) of (a): the 1755 Lisbon Earthquake (from Baptista et al., 2003) and (b): the 1969 earthquake (from Fukao, 1973).

with a magnitude $M_{\mathrm{w}} 8.3-8.5$ (Gutscher, 2004; Zitellini et al., 2001) and was followed by a devastating tsunami. For the modelling, we used the initial displacement proposed by Baptista et al. (2003) and based on a composite source assumption (Table 1 and Fig. 4a).

\subsection{Modelling results}

Scenario modelling has been performed at low tide (LT) and high tide (HT). Moreover, in order to take into account the uncertainty related to data resolution and model assumptions that could have an influence on the inundation depth and extension, additional simulation has been performed at high tide with an increase of $20 \%$ of the initial wave height (socalled augmented scenario).

Figure 5 shows the propagation of the waves generated by the two composite seismic sources of 1755 Lisbon earthquake for the augmented scenario. The waves intersected in less than $10 \mathrm{~min}$ off the Sagres coasts (Portugal) and reached the Rabat-Salé region in a little more than $43 \mathrm{~min}$. The maximum tsunami elevation field was strongly determined by the source orientation, and partly by the sea-floor bathymetry (Fig. 6a). The maximum water elevations were greater than $10 \mathrm{~m}$ near the sources as well as in the junction area of waves generated by the two sources close to Sagres Point (Portugal). The most affected Moroccan coasts were located between Rabat and Larache with heights close to $7 \mathrm{~m}$. The regional model gives details on the maximum water elevations (Fig. 6b). They were close to $2-4 \mathrm{~m} 10 \mathrm{~km}$ off the Rabat coasts and increased when approaching the coast. The local model allows confirming and refining these results. Along the Rabat and Salé coasts, maximum water elevations were between 7 and $8 \mathrm{~m}$. The values were smaller (up to
6-7 m) in the Bouregreg estuary. The maximum water elevations still reach 2 to $3 \mathrm{~m}$ at the entrance of the new marina, which now forms a part of the new residential and touristic complex on the Bouregreg river, and then decrease gradually when entering deeper in the estuary (Fig. 7). At this local scale, the maximum current velocities are greater than $3 \mathrm{~m} \mathrm{~s}^{-1}$ for the whole Rabat and Salé coasts as well as for the Bouregreg estuary (Fig. 8). The velocities are still on the order of $2 \mathrm{~m} \mathrm{~s}^{-1}, 3 \mathrm{~km}$ inside the Bouregreg river and are lower than $1 \mathrm{~m} \mathrm{~s}^{-1}$ after $5 \mathrm{~km}$.

As expected, the results of the augmented scenario show a significant increase of the maximum water elevations relative to the reference model at HT. Indeed, the results are on average 0.5 to $1 \mathrm{~m}$ greater on the Rabat and Salé coasts compared to the reference model at HT only.

A comparison of the extent of inundation for the reference scenario at low tide, the reference scenario at high tide and the augmented scenario is presented in Fig. 9. The inundation extent is greater in the augmented case but the difference is not homogeneous throughout the studied area. On the Rabat coasts and on the left-bank of the Bouregreg river, the increase between models with and without uncertainty is on the order of $20 \mathrm{~m}$ which is the grid cell size. But the difference can locally reach $100 \mathrm{~m}$ on the right-bank of the river close to the estuary due to the flat topography of this area. The lower limit of the receding sea is quite homogeneous throughout the Rabat and Salé coasts. The difference between the low tide receding sea limit and the coastline (defined at HT) is on the order of $20-40 \mathrm{~m}$ on the coasts, up to $200 \mathrm{~m}$ in the estuary, and lower than $20 \mathrm{~m}$ in the Bouregreg river with some local sea recession on the order of $100 \mathrm{~m}$. 

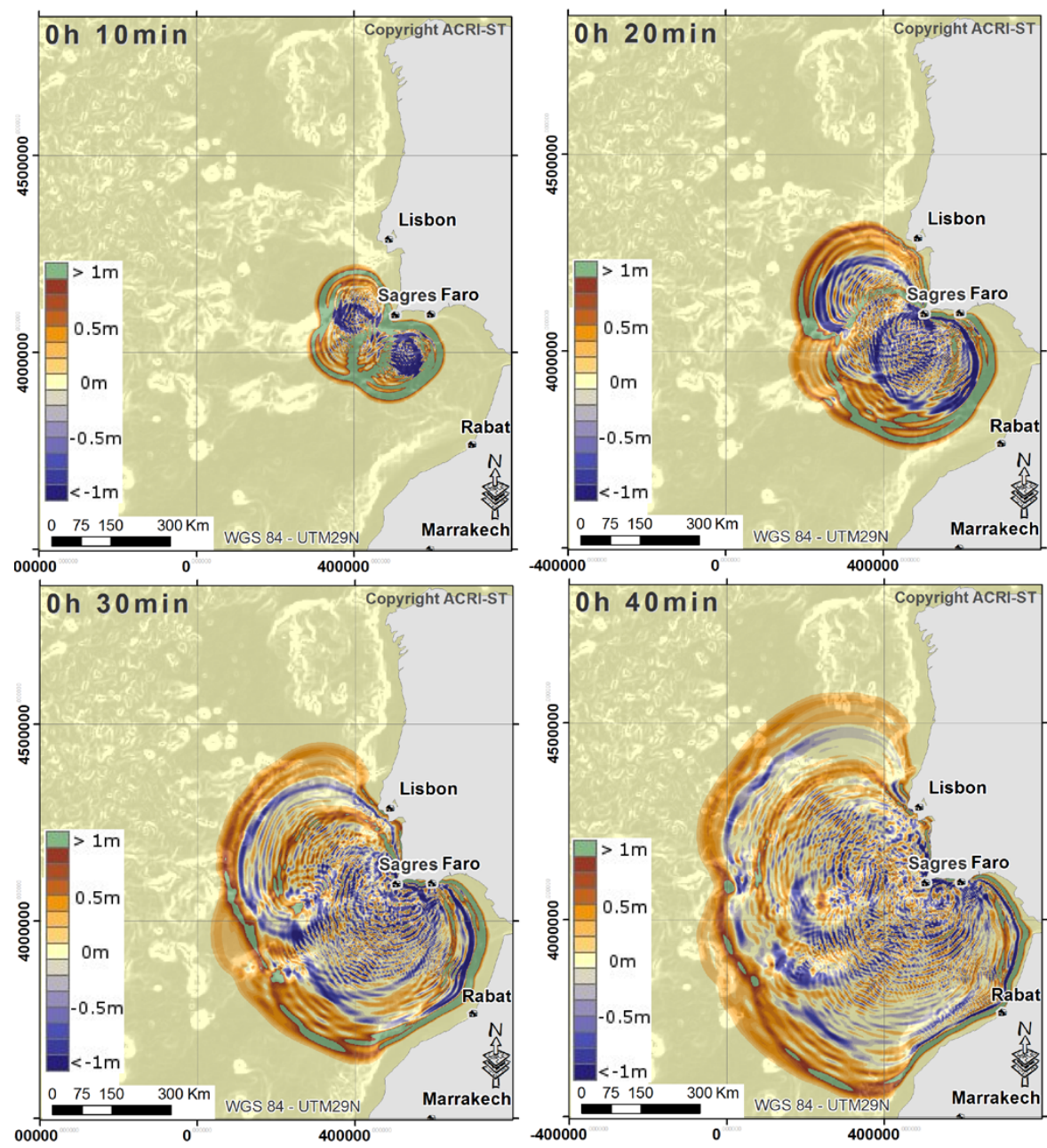

Fig. 5. Propagation steps (Lisbon large augmented scenario).

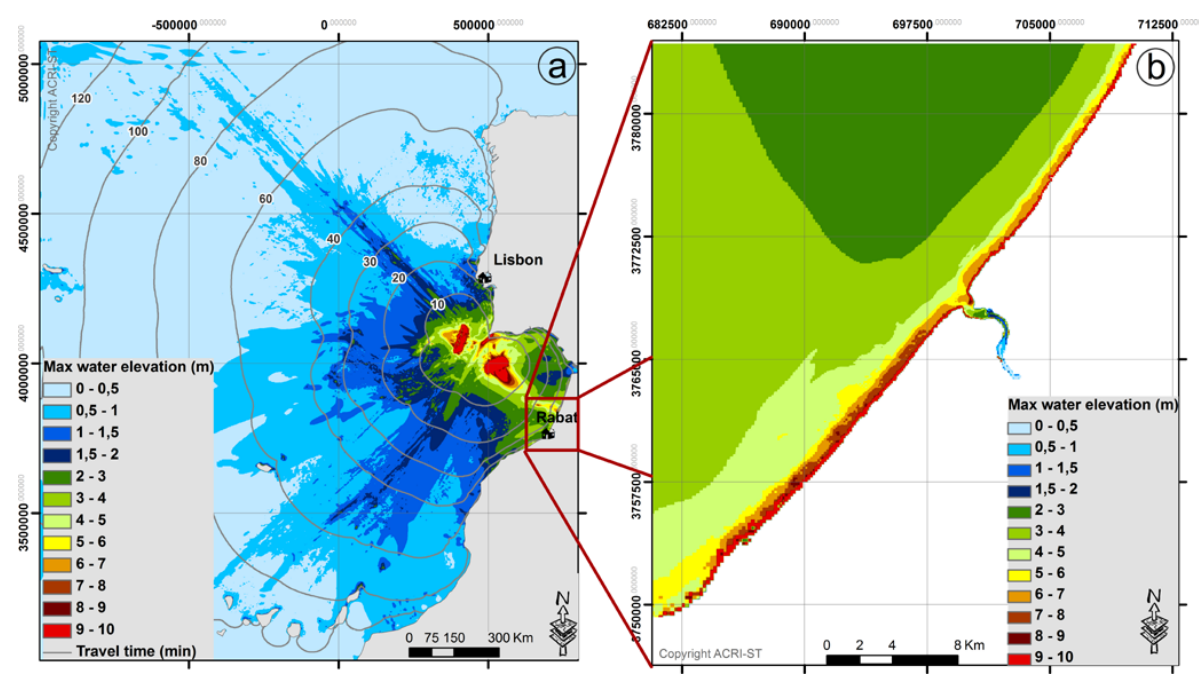

Fig. 6. Maximum water elevation - Lisbon augmented scenario ((a) large scale; (b) regional scale). 


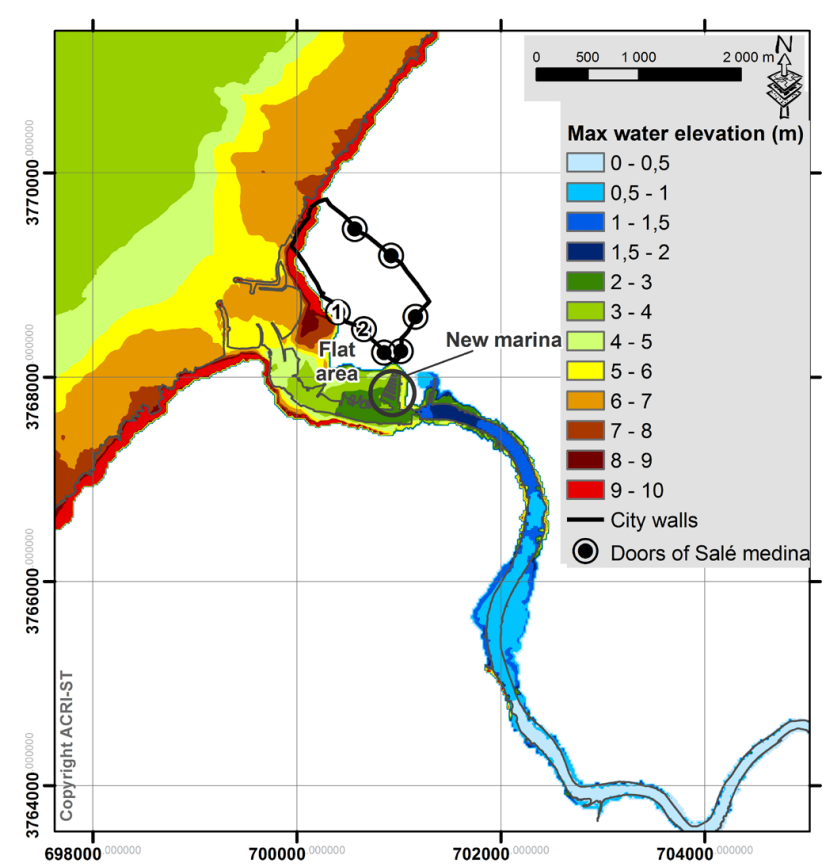

Fig. 7. Maximum water elevation (Lisbon local augmented scenario).

\subsection{Comparison between historical data and model results}

Although our goal was to obtain the damages of a future potential tsunami using the present-day conditions, a comparison between our modelling results and historical observations seemed to be relevant as we used a historical source.

The tsunami triggered by the 1755 Lisbon earthquake, took place on Saturday 1 November, 1755, at around 09:40 GMT in the morning. Taking propagation time into account, the first tsunami wave arrived at Rabat at about 10:20 a.m. GMT. At this time, the sea was close to high tide level (source: www.shom.fr). Historical observations of this event are reported in the article of Kaabouben et al. (2009).

Table 3 presents a comparison between the observed runup and the maximum water elevations at coastline modelled at high tide. The results are in quite close agreement with observations except for Tangier and Safi, for which the high values are not very plausible (values were extracted from newspapers written in 1755 based on inaccurate statements with geographical uncertainties), as pointed out by Blanc (2009). Moreover, those two locations are close to geographical limits of our model for which the vicinity of boundaries makes the elevation value unreliable.

Kaabouben et al. (2009) summarizes the historical flood descriptions of the tsunami of 1 November 1755 in Rabat and Salé: "In order to estimate the maximum inundation distance the location of the city walls was used as reference". (...) "The Medina is located inside the wall, and approxi-
Table 3. Observed runup (Kaabouben et al., 2009) and simulated max water elevations at coastline (high tide case) from the largescale model in several places on the Moroccan coasts.

\begin{tabular}{lll}
\hline Localisation & Runup observations & $\begin{array}{l}\text { Simulated max water } \\
\text { elevations }\end{array}$ \\
\hline Tangier & $15 \mathrm{~m}$ & $1.5 \mathrm{~m}$ \\
\hline Asilah & $3 \mathrm{~m}$ & $3 \mathrm{~m}$ \\
Rabat/Salé & $4 \mathrm{~m}$ & $3.5 \mathrm{~m}$ \\
El Jadida & $2.5 \mathrm{~m}$ & $2.5 \mathrm{~m}$ \\
\hline Safi & $15 \mathrm{~m}$ & $1.5 \mathrm{~m}$ \\
\hline
\end{tabular}

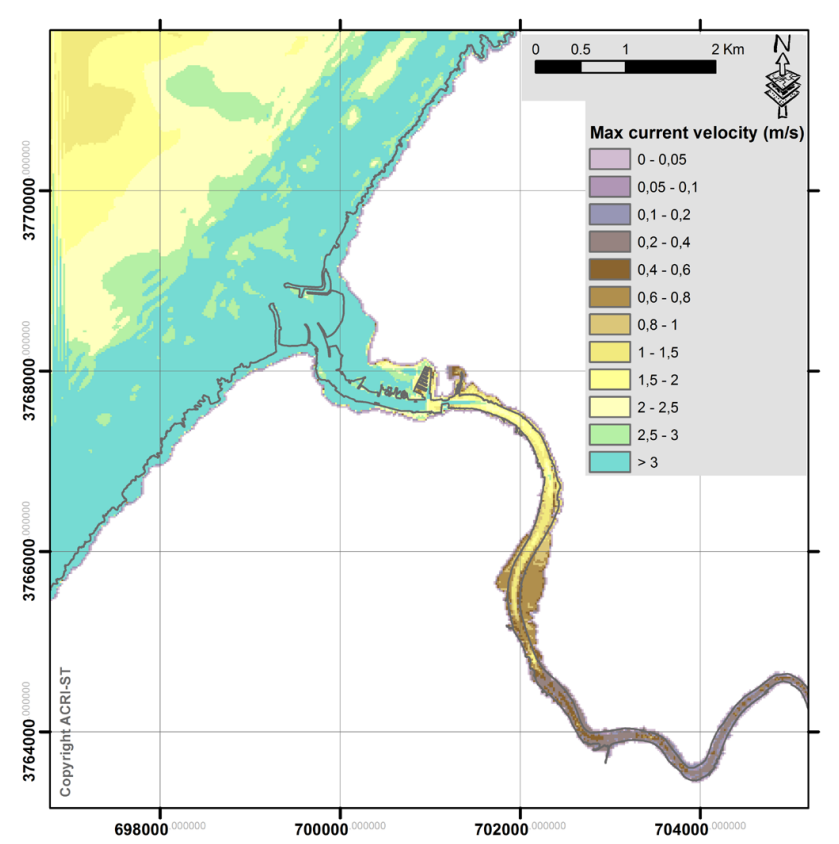

Fig. 8. Maximum current velocity (Lisbon local augmented scenario).

mately $860 \mathrm{~m}$ away from the sea." (...) "In spite of the numbers published in Arab sources," (...) "the maximum inundation distance from the coastline should not be evaluated in more than $2000 \mathrm{~m}$." Our high tide simulation of the 1755 Lisbon scenario with or without uncertainty on its seismic source gives results of the extent of inundation lower than the historical observations. These limits are locally up to $610 \mathrm{~m}$ in our modelling results. The flood would thus arrive up to the first door of Sale medina but would not affect the second door (Fig. 7). Nevertheless, the flood propagates in a significant way (more than $300 \mathrm{~m}$ wide) up to the new marina, corresponding to a distance of about $1500 \mathrm{~m}$ inland.

The deviation of the extent of inundation between simulation results and historic descriptions can be explained in several ways. First, it is possible that we did not simulate the worst case of the 1755 earthquake. Indeed, after validation 


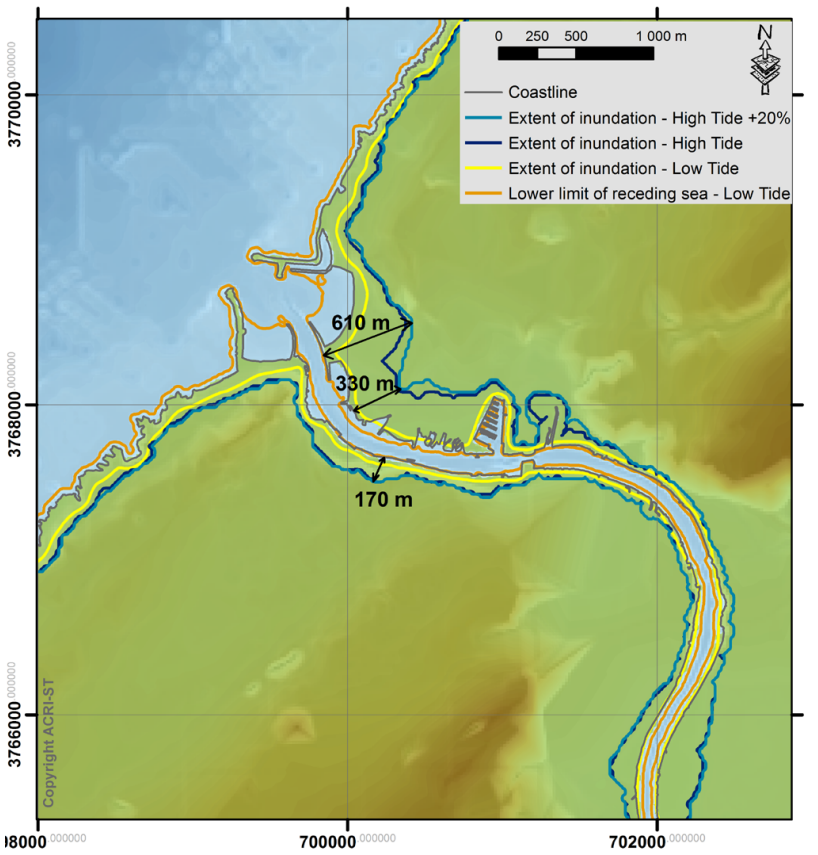

Fig. 9. Lower limit of receding sea (LT) and extent of inundation (LT, HT and augmented scenarios) - Lisbon local scenario.

of the scenario sources by the SCHEMA project, Omira et al. (2010) proposed 4 different earthquake models that had probably generated the earthquake of 1 November 1755 . The authors considered that the model 4 (N 160 source) corresponds to the worst case earthquake scenario, and assumed that all these earthquake models infer a magnitude of 8.38.5., and represent the WYCC (Worst Yet Credible Case) of a tsunami impacting Casablanca, located at $80 \mathrm{~km}$ south of Rabat. Secondly, bathymetric and topographic data used in our simulations do not correspond to the 1755 reality. Indeed, these data take into account the estuary Bouregreg dredging and the Bouregreg estuary breakwaters, which aim at protecting coast from waves. Lastly and surely the best explanation for these differences is that new districts have been built (the "quartier de la muraille" for instance) just in front of city walls between the two Salé medina doors previously mentioned. These buildings increase the topographic level of several meters and prevent flood propagation.

\subsection{Hazard assessment}

The final product of our analysis consists of a hazard map that is built by suitably combining the results (extreme values of inundation extent and inundation depths) obtained for all the different scenarios. As for the Rabat-Sale site, only one source was relevant for the worst-case scenario, and the results actually correspond to the 1755 scenario. Indeed, the SCHEMA methodology is a generic methodology aimed at application everywhere in the world. In the major-

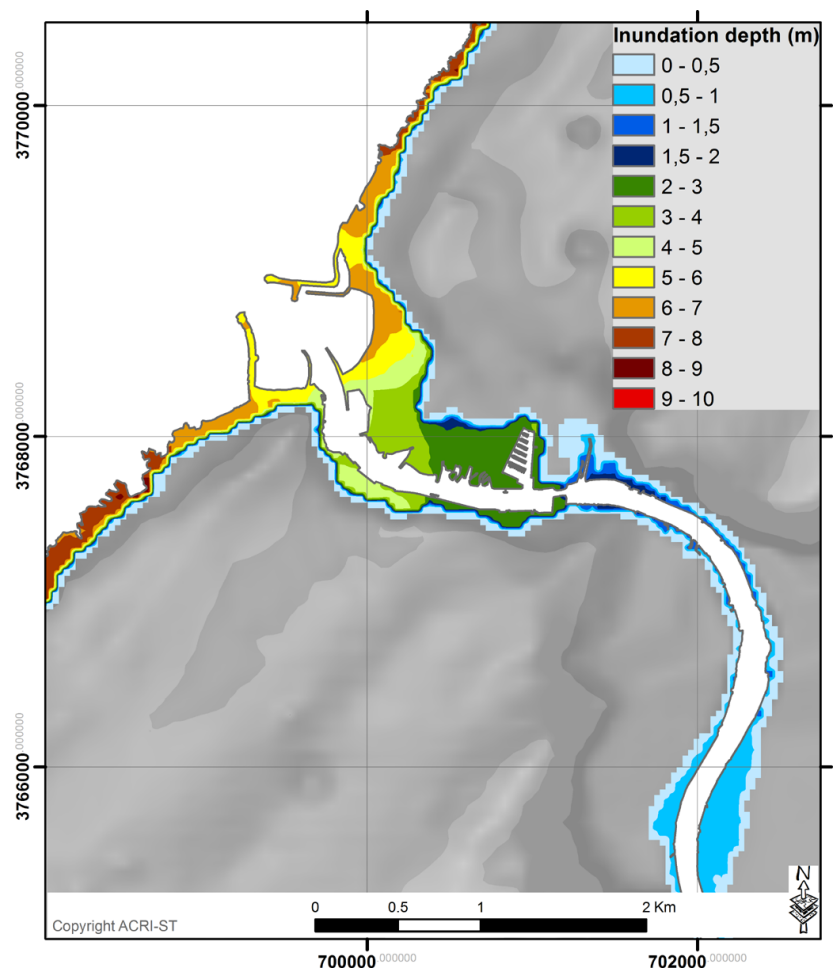

Fig. 10. Hazard map showing the inundation depths.

ity of the test sites selected for the SCHEMA project (Setubal, Portugal-Mandelieu, France-Catania, Italy (Tonini et al., 2011) - Balchik, Bulgaria), tsunami hazard does correspond to the aggregation of scenarios. Nevertheless, in some cases (like in Rabat-Salé site), historical tsunami sources may all originate from the same seismic zone, moreover, relatively far from the study site. In those cases, the wave direction of all scenarios will be almost similar and tsunami hazard will actually correspond to the highest magnitude earthquake scenario. This particular case does not prevent us from carrying out the different steps of the methodology up to the risk map. The resulting inundation depths (maximum water elevation on-land minus topography) will then serve as a foundation on which to obtain damage maps (see study results in Atillah et al., 2011).

Figure 10 shows the inundation depths ranging from 6 to $8 \mathrm{~m}$ along the Rabat and Salé coasts with punctual higher values $(8-9 \mathrm{~m})$ at the southern part of the Rabat coasts. In the flat topography area north of the Bouregreg river and upstream from the estuary, the values rapidly decrease from 6-7 to 3-4 m. The inundation depths are still around 2 to $3 \mathrm{~m}$ around and downstream from the new Bouregreg marina where a new district is under development. 


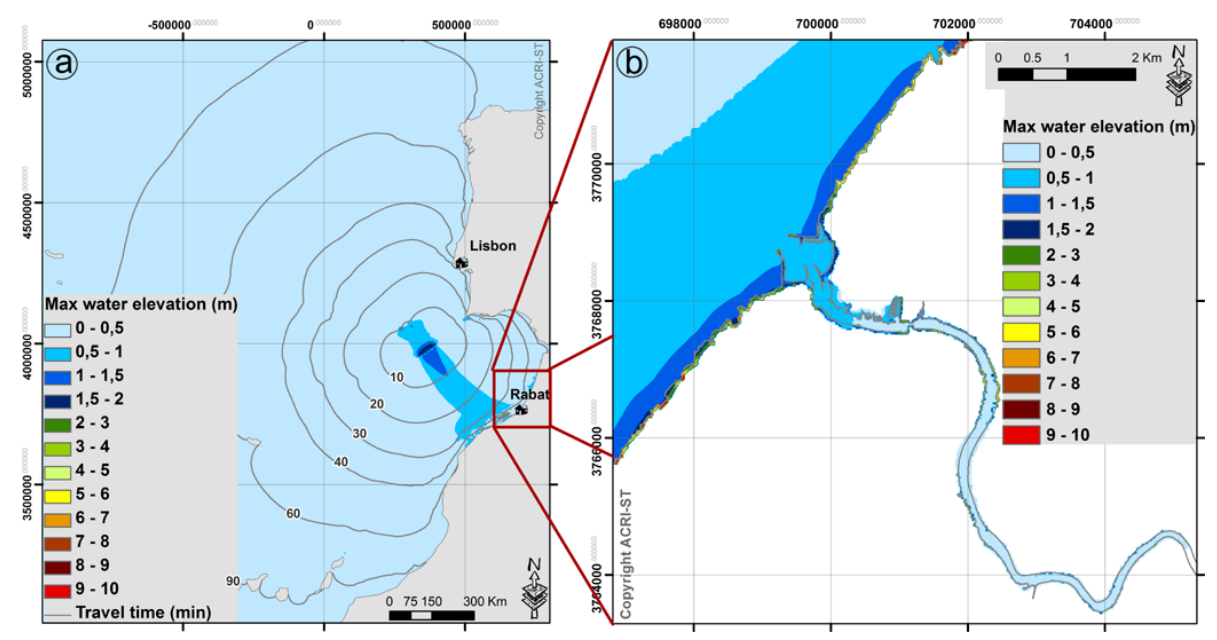

Fig. 11. Maximum water elevation - 1969 augmented Scenario ((b) large scale; (b) local scale).

\section{Discussion-moderate case}

As the SCHEMA's final purpose is land-use planning, the methodology is based on worst-case scenarios. However, sedimentary records in the Lisbon region revealed that events such as the Lisbon earthquake occur with recurrence interval of 1500 to 2000 years in the Gulf of Cadiz (Weaver et al., 2000). Moreover, some of the Moroccan users that have been contacted during the study expressed the need to have a moderate scenario for specific applications like risk mitigation or evacuation and rescue plans.

For this reason of large recurrence interval, a moderate scenario, based on the historical earthquake of 1969, common to another test site of the SCHEMA project (Setubal test site, Portugal), was also modelled. As for the 1755 scenario, the amplitude of the initial tsunami wave was increased by $20 \%$.

\subsection{Source-Horseshoe earthquake of 28 February 1969}

On 28 February 1969, an $M_{\mathrm{S}}=7.9$ submarine earthquake occurred at 02:40 (UTC) with an epicentre located south of Gorringe bank near the Azores-Gibraltar fracture zone (Fukao, 1973; Guesmia et al., 1998). It generated a small- amplitude tsunami that affected the southern coast of Spain and Portugal and the northwestern part of Morocco. Initial conditions have been computed and provided by the University of Bologna using the parameters described in Table 2 (Fig. 4b).

\subsection{Modelling results}

The computed maximum water elevations (Fig. 11a) show that most of the energy propagated perpendicularly to the fault northwestwards and in the direction of Morocco. The most affected areas were located west of Rabat and near El
Jadida and Casablanca cities. After $30 \mathrm{~min}$, the first wave started to hit Portugal and reached the Moroccan coasts only after 50 min (Fig. 11a).

At the local scale, the maximum water levels were lower than $2 \mathrm{~m}$ offshore along the Rabat and Salé coasts (Fig. 11b). The values did not exceed $1 \mathrm{~m}$ inside the estuary and decreased below $0.5 \mathrm{~m}$ only $1 \mathrm{~km}$ upstream from the estuary in the Bouregreg river.

The sea did not significantly recede as the difference between the lower limit of receding sea and the coastline was between 0 and $20 \mathrm{~m}$ except inside the estuary where it was greater (up to $200 \mathrm{~m}$; Fig. 12). The influence of the augmented scenario on the inundation extent was not very important, only $10 \mathrm{~m}$ on some areas (lower than grid resolution). Only one place close to the estuary on the right-bank of the Bouregreg river was affected by an extension of an additional $50 \mathrm{~m}$.

\subsection{Comparison between historical data and model results}

In order to compare our results with in situ data, we used the tide gauges data that were recorded for the tsunami of 28 February 1969. They are presented in the paper of Miranda et al. (1996). We digitized the Casablanca tide gauge data to be able to make a comparison with our simulation results.

As reported by Miranda et al. (1996), Omira et al. (2010) and Guesmia et al. (1998), we also observe a gap on the arrival time of tsunami wave of about $15 \mathrm{~min}$ (Fig. 13), probably due to a lack of data calibration for the Casablanca tide gauge as pointed out by Omira et al. (2010): "In the case of the February 1969 event, the unique record available to us is a hand copy drawing of the filtered signal showing a first arrival of $0.9 \mathrm{~m}$ downward". In our simulations, the highest amplitude is observed for the first wave, whereas it corresponds to the forth one in the observations. These 


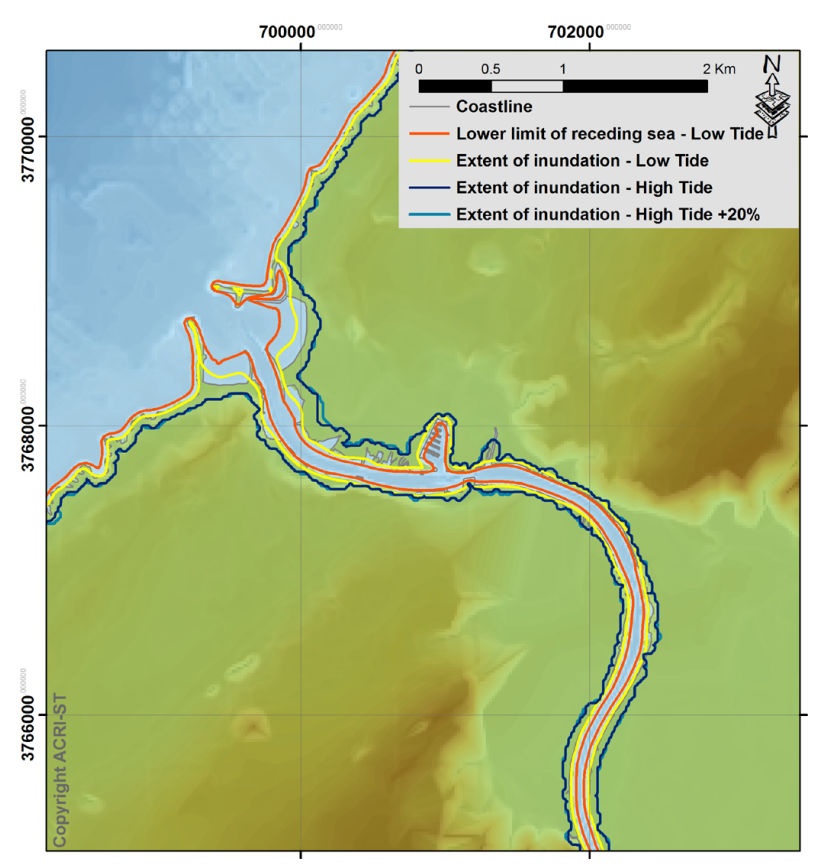

Fig. 12. Lower limit of receding sea (LT) and extent of inundation (LT, HT and augmented scenarios) - 1969 local scenario.

differences may be related to uncertainties in the source parameters (strike and dip of fault) and inaccuracy of the bathymetry (resolution of $500 \mathrm{~m}$ in Casablanca).

Concerning the maximum water elevation, our simulations give $0.95 \mathrm{~m}$ at high tide and $0.55 \mathrm{~m}$ at low tide. The tsunami event was triggered 28 February 1969 at around 02:40 a.m. GMT and the time of propagation for the wave to reach Casablanca was approximately $1 \mathrm{~h}$. At 03:40 a.m. GMT, the tide level was decreasing and was close to its average level (source: www.shom.fr). So, our simulation results are in good adequacy with the maximal wave height of Casablanca tide gauge which reaches $0.7 \mathrm{~m}$.

The extents of inundation corresponding to high tide and low tide scenarios are presented in Fig. 13. In the high tide case, the average of the horizontal extent of inundation is about $60 \mathrm{~m}$ and locally reaches $100 \mathrm{~m}$. However, at low tide conditions, the extent of inundation exceeds the coastline only locally around the Bouregreg stream bed. Given that no flood observation was reported in Rabat and Sale during the tsunami triggered by the earthquake of 28 February 1969 and taking account tide level at time of event, our results agree well with what has been reported.

\section{Conclusions}

Tsunami hazard simulations are an integral part of a general procedure for tsunami risk assessment, especially when addressing the characterization of building damage caused by tsunamis. Progress in the numerical computation for

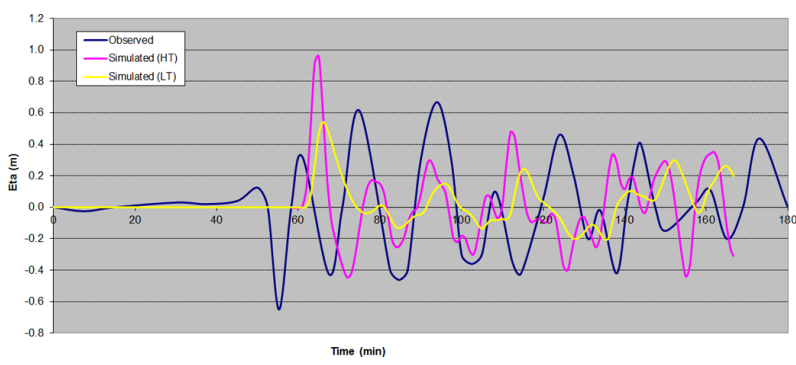

Fig. 13. Comparison between observed and simulated tide gauge (LT and HT) in Casablanca (28 February 1969).

the generation and propagation of tsunamis makes us able to rapidly obtain a reliable impact at coast in order to assess tsunami hazard. Nevertheless, it is essential to precisely build the digital topographic and bathymetric models as well as to get a more realistic definition of the worst case potential source. Indeed, these two steps can largely influence the model results.

Based on the results presented here and on a classification of building vulnerability (Atillah et al., 2011), potential damages have been derived using a relevant damage matrix, as described in the complementary study of Atillah et al. (2011).

During the SCHEMA project, this global methodology (Tinti et al., 2011) has been elaborated, tested and successfully applied on five test sites. It can be easily transposable to other sites. Tsunami risk results can then serve the decision-makers in order to take measures for land use planning (worst-case scenario) and to establish adequate evacuation plans (moderate-case scenario) in areas already urbanized or in developments like the Bouregreg valley. This methodology contributes to the tsunami risk mitigation and crisis management.

Acknowledgements. The authors wish to thank the European Commission for supporting this study through the FP6 research project SCHEMA (http://www.schemaproject.org/), Contract no. 030963 .

\section{Edited by: I. Didenkulova}

Reviewed by: S. Leschka, J. Miranda, and another anonymous referee

\section{References}

Abe, K.: Estimate of tsunami heights from earthquake magnitude, Proc of the IUGG/IOC International Symposium Wakayama, Japan, 495-507, 23-27 August 1993.

Atillah, A., El Hadani, D., Moudni, H., Renou, C., Lesne, O., Mangin, A., and F. Rouffi, Tsunami vulnerability and damage assessment in the coastal area of Rabat and Salé, Morocco, Nat. Hazards Syst. Sci., in press, 2011. 
Argus, D. F., Gordon, R. G., De Mets, C., and Stein, S.: Closure of Africa-Eurasia-North America plate motion circuit and tectonics of the Gloria fault, J. Geophys. Res., 94(B5), 5585-5602, 1989.

Baptista, M. A. and Miranda, J. M.: Revision of the Portuguese catalog of tsunamis, Nat. Hazards Earth Syst. Sci., 9, 25-42, doi:10.5194/nhess-9-25-2009, 2009.

Baptista, M. A., Miranda, J. M., Chierici, F., and Zitellini, N.: New study of the 1755 earthquake source based on multi-channel seismic survey data and tsunami modeling, Nat. Hazards Earth Syst. Sci., 3, 333-340, doi:10.5194/nhess-3-333-2003, 2003.

Blanc, P.-L.: Earthquakes and tsunami in November 1755 in Morocco: a different reading of contemporaneous documentary sources, Nat. Hazards Earth Syst. Sci., 9, 725-738, doi:10.5194/nhess-9-725-2009, 2009.

El Mrabet, T.: La séismicité historique du Maroc (en arabe), Thèse d'état de 3éme cycle, Faculté des lettres et des Sciences et Humaines, Université Mohammed V, Rabat, 291 pp., 1991.

Fukao, Y.: Thrust faulting at a lithospheric plate boundary, the Portugal earthquake of 1969, Earth Planet Sc. Lett. 18 pp., 205-216, 1973.

Garcin, M., Prame, B., Attanayake, N., De Silva, U., Desprats, J. F., Fernando, S., Fontaine, M., Idier, D., Lenotre ,N., Pedreros, R., and Siriwardana, C. H. E. R.: A Geographic Information System for Coastal Hazards. Application to a pilot site in Sri Lanka (Final Report), BRGM Open file BRGM/RP-55553-FR, 130 p., 2007.

Guesmia, M., Heinrich, P. H., and Mariotti, C.: Numerical simulation of the 1969 Portuguese tsunami by a finite element method, Nat. Hazards, 17, 31-46, 1998.

Gutscher, M. A.: What caused the Great Lisbon earthquake?, Science, 305, 1247-1248, 2004.

Kaabouben, F., Baptista, M. A., Iben Brahim, A., El Mouraouah, A., and Toto, A.: On the moroccan tsunami catalogue, Nat. Hazards Earth Syst. Sci., 9, 1227-1236, doi:10.5194/nhess-9-12272009, 2009.

Kajiura, K.: Tsunami source, energy and the directivity of wave radiation, B. Earthq. Res., 48, 835-869, 1970.

Leone, F., Lavigne, F., Paris, R., Denain, J. C., and Vinet F.: A spatial analysis of the December 26th, 2004 tsunami-induced damages: Lessons learned for a better risk assessment integrating buildings vulnerability, Appl. Geogr., 31(1), 363-375, doi:10.1016/j.apgeog.2010.07.009, 2010.

Mansinha, L. and Smylie, D. E.: The displacement field of inclined faults, Bull. Seism. Soc. Am., 61, 1433-1440, 1971.

Miranda, J. M., Miranda, P. M. A., Baptista, M. A., and Mendes Victor, L.: A Comparison of the Spectral Characteristics of Observed and Simulated Tsunamis, Phys. Chem. Earth, 21(12), 7174, 1996.
Okada, Y.: Internal deformation due to shear and tensile faults in a half-space, Bull. Seism. Soc. Am., 82, 1018-1040, 1992.

Omira, R., Baptista, M. A., Matias, L., Miranda, J. M., Catita, C., Carrilho, F., and Toto, E.: Design of a Sea-level Tsunami Detection Network for the Gulf of Cadiz, Nat. Hazards Earth Syst. Sci., 9, 1327-1338, doi:10.5194/nhess-9-1327-2009, 2009.

Omira, R., Baptista, M. A., Miranda, J. M., Toto, E., Catita, C., and Catalão, J.: Tsunami vulnerability assessment of CasablancaMorocco using numerical modelling and GIS tools, Nat. Hazards, 54, 75-95, doi:10.1007/s11069-009-9454-4, 2010.

Peiris, N.: Vulnerability functions for tsunami loss estimation. First European Conference on Earthquake Engineering and Seismology (a joint event of the 13th ECEE \& 30th General Assembly of the ESC), Geneva, Switzerland, Paper number 1121, 2006.

Serpelloni, E., Vannucci, G., Pondrelli, S., Argnani, A., Casula, G., Anzidei, M., Baldi, P., and Gasperini, P.:Kinematics of the Western Africa-Eurasia Plate Boundary From Focal Mechanisms and GPS Data, Geophys. J. Int., 169(3), 1180-1200, doi:10.1111/j.1365-246X.2007.03367.x, 2007

Tinti, S., Tonini, R., Bressan, L., Armigliato, A., Gardi, A., Guillande, R., and Scheer, S.: Handbook on Tsunami Hazard and Damage Scenarios, EUR 24691 EN, JRC61463, Luxembourg (Luxembourg), OP, 2011

Tonini, R., Armigliato, A., Pagnoni, G., Zaniboni, F., and Tinti, S.: "Tsunami hazard for the city of Catania, eastern Sicily, Italy, assessed by means of Worst-case Credible Tsunami Scenario Analysis (WCTSA)", Nat. Hazards Earth Syst. Sci., accepted, 2011.

Valencia, N., Gardi, A., Gauraz, A.L., Leone, F., and Guillande, R.: New tsunami damage functions developed in the framework of SCHEMA project: application to Euro-Mediterranean coasts, Nat. Hazards Earth Syst. Sci., under revision, 2011..

Weaver, P., Wynn, R., Kenyon, N., and Evans, J.: Continental margin sedimentation, with special reference to the north-east Atlantic margin, Sedimentology , 47(s1), 239-256, 2000.

Zitellini, N., Chierici, F., Sartori, R., and Torelli, L.: The tectonic source of the 1755 Lisbon Earthquake, Ann. Geofis., 42, 49-55, 1999.

Zitellini, N., Mendes, L.A., Cordoba, D., Danobeitia, J., Nicolich, R., Pellis, G., Ribeiro, A., Sartori, R., Torelli, L., Bartolome, R., Bortoluzzi, G., Calafato, A., Carrilho, F., Casoni, L., Chierici, F., Corela, C., Correggiari, A., Della Vedova, B., Gracia, E., Jornet, P., Landuzzi, M., Ligi, M., Magagnoli, A., Marozzi, G., Matias, L., Penitenti, D., Rodriguez, P., Rovere, M., Terrinha, P., Vigliotti, L., and Zahinos, A.: Ruiz, Source of 1755 Lisbon earthquake and tsunami investigated, EOS, 82(26), 285,290-285,291, 2001. 